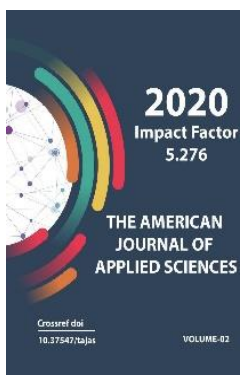

Copyright: Original content from this work may be used under the terms of the creative commons attributes 4.0 licence.

\section{Influence Of Surface Additives On Strength Indicators Of Cement Systems}

\author{
Xaydarov Abduxalil Mutalib ogli \\ Assistant, The Department Of Construction Of Buildings And Structures, Ferghana \\ Polytechnic Institute, Ferghana, Uzbekistan \\ Teshabayeva Nodira Djurayevna \\ Senior Lecturer, Department Of Construction Of Buildings And Structures, Fergana \\ Polytechnic Institute, Fergana, Uzbekistan
}

\title{
ABSTRACT
}

In the state predostavlena, $v$ issledovaniy yavilos ustanovlennbe vliyaniya dobavok poverxnostno aktivnyx veshchestv na prochnostnue pokazateli tsementnyx sistem. Definitions were made on cement of various mineralogical composition, svejemolotom and lejalom and on tsementnopeschannyx solutions and betonax.

\section{KEYWORDS}

Additives, cement, water-cement ratio, freshly ground, cement-sand mortars and concretes.

\section{INTRODUCTION}

The purpose of the research in this section was to establish the effect of surfactant additives on the strength characteristics of cement systems. The determinations were carried out on cements of various mineralogical composition, freshly ground and buried, and on cement-sand mortars and concretes.

For the control samples and with additives, the same plasticity was selected, while the water-cement ratio than for various additives fluctuated within certain limits.
The ultimate strength in compression, bending and elastic modulus were determined for mortar samples on beams $4 \times 4 \times 16 \mathrm{~cm}$ and cubes $7.07 \times 7.07 \times 7.07 \mathrm{~cm}$, and for concretes on cubes $10 \times 10 \times 10 \mathrm{~cm}$ and $20 \times 20 \times 20 \mathrm{~cm}$. It is known that in a number of cases when using mylonft there is some lack of strength at the initial stage. A decrease in the strength of products on hydrophobic cements was observed only on freshly ground cements when molding samples with a high watercement ratio. Therefore, a large number of comparative tests of the strength of samples on hydrophobic-plasticized and control 
cements were carried out. The tables below show the results of these tests.

Table reduced to the results of tests of ordinary cement

(I-B and I D and cement with a high content of $\mathrm{C} 3 \mathrm{C}$ (3-C and $5-1)$.

As follows from the data in the table, cement mortars with OP with a decrease in the watercement ratio (with different plasticity) are characterized by increased compressive and flexural strengths in comparison with the control indicators at all test periods up to a year. In this case, the optimal dosage of OP is in the range of $0.15-0.30 \%$, the strength of the samples on such cement samples increases by $10-12 \%$ compared to the control.

Mortars with OP additives, made at the same water-cement ratio as the control ones, are characterized by a shortage of strength (about 5\%) in the initial hardening period (3 days) and equalization of the strength values to 28-day hardening (cement ID).

The addition of mylonft, in spite of a decrease in the water-cement ratio, in some cases yields a $5-8 \%$ shortfall in strength compared to the control ones even after 360 days of hardening. The greatest increase in strength is achieved when using a synthetic fatty acid of the C7-C9 fraction. The introduction of this additive increases the strength of samples at 3 days of age by $50 \%$, at 28 days of age by $35 \%$ and 360 days of age - by $25 \%$.

Table the results of tests of laboratory-salted cements and solutions based on these cements are presented. The addition of oxidized petrolatum causes in all cases an increase in the strength of the cement and when tested at 3,7 and 28 days of age, despite the increase in the normal density of the cement paste, the increase in strength is explained in this case. First of all, an increase in the specific surface of cements when grinding them with OP additives. The introduction of oxidized petrolatum in an amount of $0.25 \%$ increased the plasticity of the solutions (increasing the value of the slump of the cone), did not reduce the strength parameters even with water-cement ratios the same as those adopted for the control compositions.

The results of testing solutions on slag Portland cements and clinker cements are given in table. Cement consumption in solutions with oxidized petrolatum decreased slightly in comparison with the control. Samples were subjected to normal air and water storage. As follows from the data carried out, in most cases the addition of oxidized petrolatum increased the strength of the solutions in comparison with the control. The combined addition of oxidized petrolatum and SNV somewhat lowers the strength of solutions at all test periods. Particularly interesting results were obtained when testing samples of air storage.

Samples of the composition 1: 6 on Portland cement with oxidized petrolatum showed strength at 3 days of age by $57 \%$, at 7 days of age at 100.28 days at 59 and 90 days of age, $62 \%$ higher than that of the samples on the control cement. The significant difference in strength between rigid control compositions and compositions with OP additives is explained by the difference in fluid loss rate, i.e. in the rate of drying, samples during air storage. The increased water retention capacity of solutions with OP additives provides a more intensive set of strength of solutions under conditions of air storage. This property of cements with surfactant additives is especially important for hydraulic engineering.

Table the results of physical and mechanical tests of solutions of compositions 1: 3 and 1: 6 on slag Portland cements with various additives of OP and SNV, as well as OP and SSB are given. In addition, the oxidized petrolatum was diluted with machine oil and 
sulfite-alcohol stillage and in this form was introduced directly during mixing. Solutions were prepared with a cone draft of 2 and 4 $\mathrm{cm}$.

As follows from the results of these tests, oxidized petrolatum causes negligible air entrainment, equal to $1-1.15 \%$ for fatty systems and $5-7 \%$ for lean solutions. The strength of lean solutions with additives of OP on the 7 th day at $37-52$ and on the 28th day is $15-20 \%$ higher than that of the control.

The combined addition of OP and SNV reduces the strength of mortars in fatty systems by 16 $22 \%$ and decreases their strength by $25-33 \%$ in lean cement mortars. The combined addition of OP and CER acts similarly to a mixture of OP and CER. A mixture of oxidized petrolatum with machine oil, introduced into solutions when replaced, showed an increase in strength by 7 days by $52 \%$ and at 28 days of age by $34 \%$, compared with the control, in a mixture of OP and sulfite-alcohol stillage, respectively, by $65-50 \%$.

The influence of the addition of oxidized petrolatum on the strength indicators was also tested in concretes / table 33/.

The composition of concrete was calculated using the absolute volume method, taking into account the restrictions adopted by GOST in relation to the consumption of cement, $B$ and aggregates.

\section{Results of testing cement and mortars with oxidized petrolatum additives (composition 1: 3 )}

Table 1.

\begin{tabular}{|c|c|c|c|c|c|c|c|c|c|c|c|}
\hline \multirow[t]{4}{*}{$\begin{array}{l}\text { Type of } \\
\text { cement }\end{array}$} & \multirow{2}{*}{\multicolumn{2}{|c|}{$\begin{array}{l}\text { Fineness of } \\
\text { grinding } \\
\text { residues on } \\
\text { sieves, } \%\end{array}$}} & \multirow{4}{*}{$\begin{array}{l}\text { Normal } \\
\text { consiste } \\
\text { ncy of } \\
\text { cement } \\
\text { paste }\end{array}$} & \multicolumn{3}{|c|}{$\begin{array}{l}\text { Uniformity in the } \\
\text { volume } \\
\text { distribution of the } \\
\text { mixture }\end{array}$} & \multicolumn{2}{|c|}{$\begin{array}{l}\text { Curing } \\
\text { time of the } \\
\text { mixture }\end{array}$} & \multirow{3}{*}{\multicolumn{3}{|c|}{$\begin{array}{l}\text { Testing of cement } \\
\text { according to } \\
\text { GOST } 31108- \\
2016 \\
\text { Temporary } \\
\text { increase in } \\
\text { compressive } \\
\text { strength } \mathrm{kg} / \mathrm{cm}^{2}\end{array}$}} \\
\hline & & & & \multirow{3}{*}{$\begin{array}{l}\text { wate } \\
\mathrm{r}\end{array}$} & \multirow{3}{*}{$\begin{array}{l}\text { in } \\
\text { ste } \\
\text { am }\end{array}$} & \multirow{3}{*}{$\begin{array}{l}\text { boili } \\
\text { ng }\end{array}$} & \multirow{3}{*}{$\begin{array}{l}\text { Begi } \\
\text { nnin } \\
\text { g }\end{array}$} & \multirow{3}{*}{$\begin{array}{l}\text { the } \\
\text { end }\end{array}$} & & & \\
\hline & \multirow[t]{2}{*}{$\begin{array}{l}900 \\
\text { holes }\end{array}$} & \multirow{2}{*}{$\begin{array}{l}4900 \\
\text { hole } \\
\text { s }\end{array}$} & & & & & & & & & \\
\hline & & & & & & & & & 3 & 7 & 28 \\
\hline No additive & $\begin{array}{l}0,365 \\
0,365\end{array}$ & $\begin{array}{l}7,48 \\
5 \\
7,48 \\
5\end{array}$ & $\begin{array}{l}22 \\
22\end{array}$ & $\begin{array}{l}\text { W } \\
\text { W }\end{array}$ & $\begin{array}{l}\mathrm{S} \\
\mathrm{S}\end{array}$ & $\begin{array}{l}b \\
b\end{array}$ & $\begin{array}{l}2^{20} \\
2^{20}\end{array}$ & $\begin{array}{l}4^{10} \\
4^{10}\end{array}$ & $\begin{array}{l}218 \\
218\end{array}$ & $\begin{array}{l}297 \\
297\end{array}$ & \\
\hline $\begin{array}{l}\text { With } \\
\text { additive OP- } \\
0,15\end{array}$ & $\begin{array}{l}0,176 \\
0,176\end{array}$ & $\begin{array}{l}2.1 \\
2.1\end{array}$ & $\begin{array}{l}25 \\
25\end{array}$ & $\begin{array}{l}\mathrm{W} \\
\mathrm{W}\end{array}$ & $\begin{array}{l}\mathrm{S} \\
\mathrm{S}\end{array}$ & $\begin{array}{l}b \\
b\end{array}$ & $\begin{array}{l}2^{55} \\
2^{55}\end{array}$ & $\begin{array}{l}4^{55} \\
4^{55}\end{array}$ & $\begin{array}{l}242 \\
242\end{array}$ & $\begin{array}{l}349 \\
349\end{array}$ & \\
\hline $\begin{array}{l}\text { With } \\
\text { additive } \\
\text { OP - } 0,25\end{array}$ & $\begin{array}{l}0,15 \\
0,15\end{array}$ & $\begin{array}{l}1,45 \\
1,45\end{array}$ & $\begin{array}{l}25 \\
25\end{array}$ & $\begin{array}{l}\mathrm{W} \\
\mathrm{W}\end{array}$ & $\begin{array}{l}\mathrm{S} \\
\mathrm{S}\end{array}$ & $\begin{array}{l}b \\
b\end{array}$ & $\begin{array}{l}2^{43} \\
2^{43}\end{array}$ & $\begin{array}{l}5^{25} \\
5^{25}\end{array}$ & $\begin{array}{l}303 \\
303\end{array}$ & $\begin{array}{l}400 \\
400\end{array}$ & \\
\hline $\begin{array}{l}\text { With } \\
\text { additive OP - } \\
0,10 \mathrm{SNV} \text { - } \\
0,015\end{array}$ & 0,15 & 2,0 & 25 & $\mathrm{~W}$ & $\mathrm{~S}$ & $\mathrm{~b}$ & $3^{2}$ & $5^{40}$ & 287 & 411 & \\
\hline
\end{tabular}


Table continuation

\begin{tabular}{|c|c|c|c|c|c|c|c|c|c|c|c|}
\hline \multirow{2}{*}{\multicolumn{3}{|c|}{$\begin{array}{l}\text { temporary } \\
\text { resistance to } \\
\text { bending } \\
\text { depending on age } \\
\mathrm{kg} / \mathrm{cm}^{2}\end{array}$}} & \multirow{4}{*}{$\begin{array}{l}\text { subsidence } \\
\text { of the } \\
\text { cone } \mathrm{cm}\end{array}$} & \multirow[t]{4}{*}{$\frac{\mathrm{W}}{\mathrm{S}}$} & \multirow{4}{*}{$\begin{array}{l}\text { bulk } \\
\text { density of } \\
\text { the } \\
\text { mixture is } \\
\mathrm{kg} / \mathrm{dm}^{3}\end{array}$} & \multicolumn{6}{|c|}{$\begin{array}{l}\text { limit state of compressive strength } \mathrm{kg} / \\
\mathrm{cm}^{2}\end{array}$} \\
\hline & & & & & & \multirow{2}{*}{\multicolumn{3}{|c|}{$\begin{array}{l}\text { Samples stored in } \\
\text { normal condition }\end{array}$}} & \multirow{2}{*}{\multicolumn{3}{|c|}{$\begin{array}{l}\text { Samples stored in } \\
\text { aqueous state }\end{array}$}} \\
\hline \multirow[t]{2}{*}{3} & \multirow[t]{2}{*}{7} & \multirow[t]{2}{*}{28} & & & & & & & & & \\
\hline & & & & & & 3 & 72 & 28 & 7 & 28 & \\
\hline 15,7 & 17,7 & & 4,5 & 0,54 & 2,13 & 76 & 84 & 165 & 102 & 197 & \\
\hline 15,7 & 17,7 & & 4,0 & 0,58 & 2,23 & 49 & 130 & 171 & 130 & 191 & \\
\hline 14,8 & 19,2 & & 5,5 & 0,545 & 2,10 & 53 & 76 & 168 & 98 & 145 & \\
\hline 14,8 & 19,2 & & 5,5 & 0,53 & 2,16 & 68 & 104 & 162 & 112 & 192 & \\
\hline 18,5 & 22,5 & & 5,5 & 0,545 & 2,09 & 72 & 86 & 1447 & 102 & 187 & \\
\hline 18,5 & 22,5 & & 6 & 0,53 & 2,15 & 75 & 121 & 170 & 104 & 193 & \\
\hline 18,2 & 1,7 & & 6 & 0,53 & 2,15 & 61 & 96 & 151 & 103 & 185 & \\
\hline
\end{tabular}

\section{REFERENCES}

1. Draft Land Code of the Republic of Uzbekistan in the new edition. ID3399

2. Abdullayev SA,Ziyomukhammedov EA Efficient use of land resources is a requirement of the time.Collection "Problems of land use organization and land cadaster.T.TIMI,2005, pages 65-69.

3. Bobojonov $A, R$, Rahmonov Q.R, G'ofurov A.J."There is a cadaster. T.,"Cholpon", 2002.

4. Teshaboeva N.D. The use of mineral fillers and chemical addives ACF, surfactants of a multifunctional purpose, in the production of cement, monolithic and prefabricated No.12(69)/2019 4 part.

5. Тешабоева Н.Д.Улучшение структуры и свойства бетона в условиях сухого жаркого климата гидрофобно- пластифицирующей добавкой. ЕВРАЗИЙСКИЙ $\mathrm{COЮ3}$
УЧЕНЫХ (ЕСУ) Ежемесячный научный журнал.№ 3 (72)/ 20202 часть

6. Тешабоева Н. А. Способ определения капиллярной проницаемости бетона в условиях сухого жаркого климата. ЕВРАЗИЙСКИЙ СОЮЗ УЧЕНЫХ (ЕСУ) Ежемесячный научный журнал № 10 (67)/ 2019.7 часть

7. Тешабоева Н.Д. Использование минеральных напольнителей и химической добавки АЦФ, ПАВ полифункционального назначения, при производстве цемента, монолитных и сборных № 12 (69) / 20194 часть.

8. Тешабоева Н.Д.Влияния высыхания Аральского моря и сухого жаркого климата Центральной Азии на несущие и ограждающие конструкции и зданий и сооружений.Молодой ученный. №20. (258).Май 2019.

9. Тешабоева Н.Д. IMPROVEMENT OF THE STRUCTURE AND PROPERTIES OF CONCRETE UNDER THE CONDITIONS OF DRY HOT CLIMATE HYDROPHOBIC 
- PLASTIC ADDITIVE. INTERNATIONAL JOURNAL OF RESEARCH CULTURE SOCIETY . Monthly, Peer-Reviewed, Refereed, Indexed Journal . Accepted on : 20/11/2019

10. Тешабоева Н.Д. Surface identification methods uztd in land managtmtnt and land cadaster. Academia an international multidisciplinaru Rrsrach Journal/ vol/10/issut 8/2020/98-103

11. Xaydarov Abduxalil Mutalib Ogli, Development of effective cement additives for the production of heatresistant concrete based on technogenic waste "International Journal of Researchculture Society" India (2019. 12. 12)

12. Mirzajonovich, Q. G., Ogli, A. U. A., \& Ogli, X. A. M. (2020). Influence Of Hydro Phobizing Additives On Thermophysical Properties And LongTerm Life Of Keramzitobetona In An Aggressive Medium. The American Journal of Engineering and Technology, 2(11), 101-107.

13. Ogli, X. A. M., Ogli, A. U. A., \& Mirzajonovich, Q. G. (2020). Ways Of Implementation Of Environmental Emergency Situations In Engineering Preparation Works In Cities. The American Journal of Engineering and Technology, 2(11), 108-112.

14. Mirzaahmedov, A. T. (2020). Accounting For Non-Linear Work Of Reinforced Concrete In The Algorithms Of Calculation And Design Of Structures. The American Journal of Engineering and Technology, 2(11), 5466.

15. Ogli, A. U. A., Ogli, X. A. M., \& Mirzajonovich, Q. G. (2020). Hazrati Imam Architecture The Complex Is A Holiday Of Our People. The American Journal of Engineering and Technology, 2(11), 46-49. 